\title{
Komputasi Tingkat Kesehatan Instalasi Listrik pada Gedung
}

\author{
Fauzun Atabiq*, Yohanes Suyanto" $^{\#}$ \\ * Batam Polytechnics \\ Electrical Engineering study Program \\ Parkway Street, Batam Centre, Batam 29461, Indonesia \\ E-mail: atabiq@polibatam.ac.id. \\ \# Gadjah Mada University \\ Department of Computer Science and Electronics \\ Sekip Utara, Bulaksumur, Yogyakarta 55281 Indonesia \\ E-mail: yanto@ugm.ac.id
}

\begin{abstract}
Abstrak
Kesehatan instalasi listrik gedung adalah kondisi mengenai baik buruknya integritas instalasi listrik sistem instalasi listrik pada suatu gedung. Tujuan dari penelitian ini adalah mengembangkan sebuah teknik evaluasi kesehatan instalasi listrik untuk menentukan tingkat kesehatan instalasi listrik pada sebuah gedung/bangunan. Sebuah sistem komputasi kesehatan instalasi listrik telah dimodelkan untuk mengevaluasi tingkat kesehatan instalasi kelistrikan pada sebuah gedung berdasarkan parameter-parameter instalasi. Dengan melakukan ekivalen analisis terhadap beberapa parameter instalasi seperti; usia instalasi, pembebanan circuit breaker, pembebanan pada kabel, ketidakimbangan beban instalasi dan temperatur pada panel di setiap panel instalasi listrik yang ada pada gedung, kondisi kesehatan instalasi listrik sebuah gedung dapat ditentukan. Dari implementasi yang dilakukan pada instalasi listrik Gedung S2/S3 FMIPA UGM pada bulan Maret - April 2016, hasil penelitian memperlihatkan bahwa tingkat kesehatan instalasi listrik Gedung S2/S3 FMIPA UGM secara keseluruhan adalah di atas 7.0, atau secara garis besar menunjukkan bahwa kondisi kesehatan instalasi listrik pada gedung tersebut adalah baik.
\end{abstract}

Kata kunci: Komputasi, Tingkat kesehatan, Instalasi listrik.

\begin{abstract}
Health of electrical installation is the condition about integrity or how well an electrical installation in the building electrical installation system. The health of electrical installation on the building is closely related to the quality and safety of electrical installation system which in turn will affect to the value of the reliability of the building electrical installation systems. In this study a computation system is modeled to evaluate and determine the health indices of electrical installation on the building. By equivalece analysis of several installation parameters, such as; age of the installation, load of circuit breakers, load of installation cables, load unbalanced factor, and the ambient temperature on any existing electrical installation panels in the building, the health of electrical installation system on the building can be determined. From evaluation carried out in electrical installations of Gedung S2/S3 FMIPA UGM between March-April 2016, the results showed that generally the health of electrical installations in building is good. In scale 1 to 10, the health indices of electrical installations in Gedung S2/S3 FMIPA UGM as a whole is above 7.0.
\end{abstract}

Keywords: Computation, Health Indices, Electrical Installation. 


\section{Pendahuluan}

Kesehatan instalasi listrik gedung adalah kondisi mengenai baik buruknya integritas suatu instalasi listrik dalam sebuah sistem instalasi listrik pada gedung. Kesehatan instalasi listrik pada sebuah gedung sangat berkaitan erat dengan quality dan safety sistem instalasi listrik gedung yang pada gilirannya akan mempengaruhi nilai reliability dari sistem instalasi listrik pada sebuah gedung.

Sistem instalasi listrik merupakan bagian insfratrukstur yang vital dalam sebuah gedung atau bangunan. Namun demikian tidak jarang dijumpai prilaku penggunaan listrik yang asal-asalan (poor installation and utilization practice) sehingga menyebabkan memburuknya kondisi instalasi, kerusakan dan bahkan terjadinya bahaya kebakaran pada perangkat instalasi listrik gedung [1]. Masih sering dijumpainya peristiwa kebakaran gedung/bangunan yang disebabkan karena korsleting listrik, menunjukkan bahwa kualitas/kondisi instalasi listrik pada suatu gedung/bangunan adalah tidak selalu terjamin dengan baik. Oleh karena itu untuk menjaga kondisi/kualitas instalasi listrik dapat terjamin dengan baik, menjaga keamanan instalasi dan perlengkapannya, keamanan gedung beserta isinya, dan terjaminnya keberlangsungan kegiatan operasional di dalam gedung, maka evaluasi kesehatan instalasi listrik pada gedung secara berkala menjadi sangat penting untuk dilakukan.

Di dalam sistem pemanfaatan ketenagalistrikan sistem instalasi listrik gedung adalah sebuah sistem yang sangat kompleks. Hal ini karena banyak faktor yang beberapa diantaranya adalah karena ukuran fisiknya, banyaknya komponen instalasi, sambungan dan saling terintegrasi antara sirkit yang satu dengan yang lainnya (sheer physical size), dan juga perilaku sistem pada satu titik di dalam sistem yang tidak terprediksi (unpredicted system behavior) namun dapat memiliki suatu dampak besar yang jauh dari sumber masalahnya [2], sehingga ini menjadi kendala tersendiri untuk mengevaluasi kesehatan instalasi listrik pada sebuah gedung/bangunan.

Belum adanya piranti (tools) serta minimnya teknik/metode dalam mengevaluasi kesehatan instalasi listrik adalah kendala utama untuk mengevaluasi kondisi instalasi listrik pada sebuah gedung/bangunan. Untuk menilai kesehatan instalasi listrik suatu gedung/bangunan saat ini pada umumnya masih dilakukan secara manual yaitu melalui kegiatan audit elektrikal, studi kelayakan instalasi atau verifikasi instalasi kelistrikan. Beberapa kendala dari kegiatan ini adalah dibutuhkannya orang-orang khusus yaitu mereka yang memiliki keahlian pada bidang teknik ketenagalistrikan atau memiliki sertifikasi khusus sebagai auditor instalasi sehingga terbatas hanya bisa dilakukan oleh orang-orang tertentu. Selain itu dibutuhkannya beberapa peralatan instrumentasi (seperti: merger, thremography infrared, dll.), serta biaya yang tidak sedikit untuk menyewa jasa auditor elektrikal diperlukan suatu cara alternatif untuk mengevaluasi kesehatan instalasi listrik sehingga bisa dilakukan oleh setiap pemilik atau pengelola gedung secara berkala.

Tujuan dari penelitian ini adalah mengembangkan sebuah teknik evaluasi kesehatan instalasi listrik pada gedung/bangunan. Sebuah sistem komputasi kesehatan instalasi telah dimodelkan untuk mengevaluasi dan menentukan tingkat kesehatan instalasi listrik pada sebuah gedung/bangunan. Berdasarkan parameter-parameter instalasi seperti; usia instalasi, faktor pembebanan circuit breaker, pembebanan pada kabel instalasi, ketidakimbangan distribusi beban, dan temperatur pada panel, kesehatan instalasi listrik pada gedung dapat dievaluasi berdasarkan aturan-aturan di dalam instalasi ketenagalistrikan.

\section{Metode Penelitian}

Pada penelitian ini untuk mengevaluasi kesehatan instalasi listrik suatu gedung, sebuah sistem model komputasi dikembangkan. Dengan melakukan pengamatan dan pengukuran beberapa parameter instalasi listrik seperti; usia instalasi gedung, faktor pembebanan pada $\mathrm{CB}$, pembebanan pada kabel-kabel instalasi, ketidakimbangan distribusi beban, dan temperatur pada panel listrik di setiap panel instalasi yang ada pada gedung, sistem akan melakukan evaluasi melalui ekivalen analisis terhadap parameter-parameter instalasi untuk digunakan sebagai variabel-variabel input sistem dalam menentukan kesehatan instalasi listrik gedung. Sebagai objek penelitian dan pengujian hasil pemodelan, model komputasi digunakan untuk mengevaluasi dan menentukan tingkat kesehatan instalasi listrik pada Gedung S2/S3 FMIPA UGM Yogyakarta. Oleh karena untuk menyelesaikan penelitian ini ada empat tahapan yang dilalui yaitu akusisi pengetahuan, analisis dan desain, implementasi, dan pengujian.

\subsection{Akusisi Pengetahuan}

Dua jenis pengetahuan penting sebagai basis pengetahuan dalam penelitian adalah pengetahuan terkait dengan instalasi requirement pada gedung objek penelitian dan aturan-aturan, regulasi atau standar-standar tentang instalasi kelistrikan. Basis pengetahuan adalah seperangkat aturan yang menjelaskan pengetahuan domain untuk digunakan dalam pemecahan masalah [4]. Beberapa aturan kelistrikan yang dijadikan sumber pengetahuan dalam penelitian ini adalah seperti (meskipun tidak terbatas hanya pada);

a. UU No. 30 Tahun 2009 tentang ketenagalistrikan. 
b. SNI 04-0225-2000 tentang Peraturan Umum Instalasi Listrik (PUIL 2000) Jakarta.

c. Electrical Installation Guide 2009 According to IEC International Standar, Schneider Electric, (2008).

d. Standar instalasi listrik dari NEMA, jurnal ilmiah ketenagalistrikan dan pengetahuan dari ahli/pakar ketenagalistrikan, dll.

\section{2 Analisis dan Desain}

Instalasi listrik objek penelitian adalah instalasi listrik sistem tiga fase. Objek penelitian merupakan gedung 5 lantai yang bentuk instalasi listriknya dipisahkan oleh panel-panel hubung bagi (PHB) di setiap lantainya sesuai dengan fungsi peruntukan masing-masing. Total ada 12 panel SSDP yang tersebar di setiap lantai dan 1 panel SDP yang ada pada lantai Basement (Gambar 1). Mengacu pada usia banguan, usia instalasi listrik pada gedung objek penelitian masih tergolong baru, yakni sampai penelitian ini dilakukan instalasi kelistrikan gedung objek penelitian masih berusia sekitar 4 tahun.

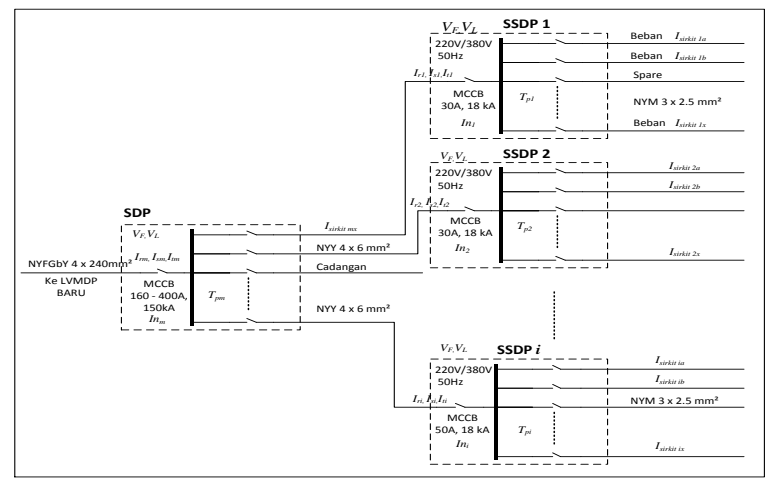

Gambar 1. Ekivalen model sistem instalasi listrik gedung S2/S3 FMIPA UGM

Berdasarkan UU No. 30 Tahun 2009 tentang ketenagalistrikan disebutkan bahwa pada dasarnya setiap instalasi listrik yang telah beroperasi adalah laik (qualified), telah memenuhi unsur quality dan safety instalasi listrik yang dipersyaratkan. Namun demikian seiring bertambahnya usia instalasi (service live) maka instalasi listrik dan peralatannya akan mengalami degadrasi dan deteriorasi [5]. Selain itu dalam basis pengetahuan instalasi listrik untuk menjamin quality dan safety sistem suatu instalasi listrik beberapa diantaranya dinyatakan bahwa; setiap peralatan instalasi listrik tidak boleh dibebani melebihi kemampuannya [6]. Bertambahnya beban akan meningkatkan temperatur pada kabel-kabel dan isolator-isolator peralatan instalasi. Meningkatnya temperatur pada peralatan instalasi akan berdampak pada berkurangnya umur hidup (working live) peralatan instalasi [3]. Suhu berlebihan yang sangat mungkin mengakibatkan kebakaran, luka bakar atau efek cedera lain [6], salah satu faktor yang mungkin berpengaruh menyebabkan efek merusak perlengkapan atau menggangu suplai selama pelayanan normal antara lain adalah beban tak imbang [6], akibat pembebanan yang tidak seimbang menyebabkan rugi-rugi daya dalam penyaluran energi listrik semakin besar [7], dll.

Oleh karena itu untuk menentukan tingkat kesehatan instalasi listrik pada sebuah gedung/bangunan maka dapat dilakukan dengan pendekatan mengevaluasi terhadap kualitas pembebanan peralatan instalasi (load margin) dan kondisi (integrity) instalasi sebagaimana diperlihatkan pada Gambar 2.

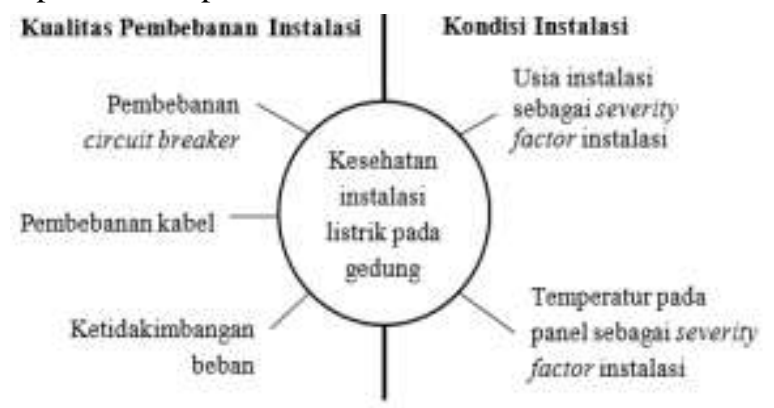

Gambar 2. Diagram proses komputasi kesehatan instalasi berdasarkan parameter instalasi

\subsubsection{Desain Model}

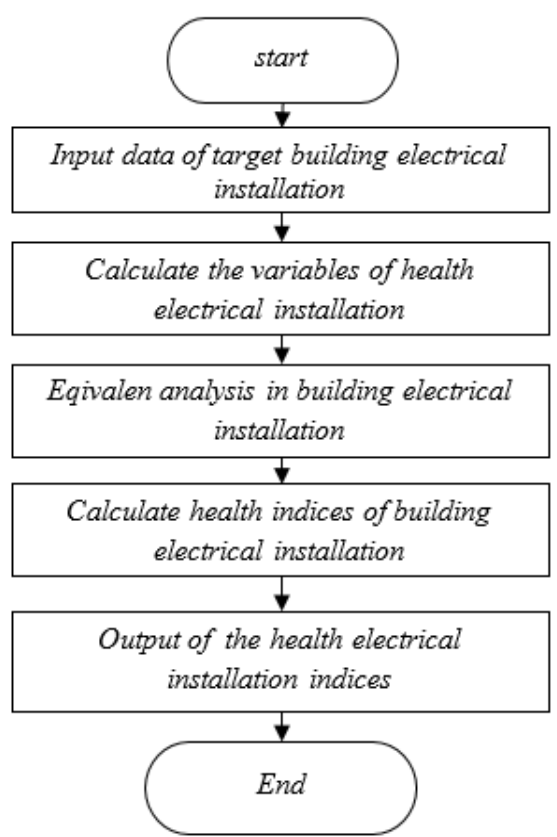

Gambar 3. Diagram alir tahapan proses komputasi menentukan tingkat kesehatan instalasi listrik pada gedung

Melalui evaluasi terpisah di setiap panel instalasi listrik pada gedung, yang dimulai dari panel beban (SSDP) di setiap lantai hingga panel cabang (SDP) pada gedung, evaluasi kesehatan instalasi listrik gedung secara keseluruhan dapat dilakukan. Sebagaimana diperlihatkan pada Gambar 3 proses komputasi kesehatan instalasi untuk mengevaluasi dan 
menentukan tingkat kesehatan instalasi listrik pada gedung secara garis besar ada 4 tahapan yaitu:

a) Memasukkan parameter-parameter instalasi dari gedung yang dievaluasi, yang meliputi; usia instalasi $(U)$, nilai rating circuit breaker utama $(I n)$, arus beban di setiap saluran fase $(I r, I s, I t)$, jenis dan ukuran sampling pembebanan kabel, arus sirkit (Isirkit), dan temperatur pada panel (Tp).

b) Menggunakan parameter-parameter instalasi untuk menentukan variabel-variabel kesehatan instalasi, yaitu variabel pembebanan circuit breaker utama $\left(l_{c b}\right)$, varaiabel ketidakimbangan beban $(\mathcal{E})$, dan variabel pembebanan kabel $(l b)$.

c) Melakukan ekivalen analisis setiap variabel instalasi.

d) Menentukan kondisi tingkat kesehatan instalasi (h).

\subsubsection{Input-Output Model}

Untuk mengevaluasi kesehatan instalasi listrik pada setiap panel listrik dalam gedung maka parameter-parameter instalasi listrik selanjutnya digunakan untuk menentukan variabel-variabel kesehatan instalasi listrik. Sistem komputasi kesehatan instalasi instalasi listrik pada gedung terdiri atas 5 variabel input, 1 variabel output. Variabel output adalah kondisi kesehatan instalasi $(h)$. Variabel input meliputi pembebanan circuit breaker (lcb), pembebanan kabel instalasi $(l b)$, ketidakimbangan beban $(\mathcal{E})$, usia instalasi $(u)$ dan temperatur pada panel (tp). Variabel-variabel input sistem komputasi ini ditentukan berdasarkan nilai-nilai parameter instalasi hasil pengamatan pada instalasi listrik gedung yang dievaluasi menggunakan Persamaan (1) s.d (6).

$$
\begin{aligned}
& C B_{C}=\left(\sqrt{3} V_{L} I_{n}\right) / 1000 \\
& C B_{L}=\left(V_{F}\left(I_{R}+I_{S}+I_{T}\right)\right) / 1000 \\
& l c b=\left(C B_{L} / C B_{C}\right) \times 100 \% \\
& l b=\left(I_{\text {Sirkit }} / \text { KHA }_{\text {Sirkit }}\right) \times 100 \% \\
& \varepsilon=\frac{\text { simpangan maksimum dari rerata }\left\{I_{R}, I_{S_{i}}, I_{T}\right\}}{\text { rerata }\left\{I_{R}, I_{S}, I_{T}\right\}} \times 100 \% \\
& h_{\mathrm{i}}=f\left(l_{c b_{\mathrm{i}},}, l_{b_{\mathrm{i}},}, \varepsilon_{\mathrm{i}}, u_{\mathrm{i}}, t_{p_{\mathrm{i}}}\right)
\end{aligned}
$$

Dengan $V_{L}$ merupakan tegangan pengenal saluran (V), $I_{n}$ adalah nilai rating $\mathrm{CB}(\mathrm{A}), I_{\text {Sirkit }}$ adalah arus yang mengalir melalui kabel yang diamati (A), $K H A_{\text {Sirkit }}$ adalah nilai KHA dari kabel yang diamati (A), $V_{F}$ adalah tegangan pengenal fase ke netral $(\mathrm{V}), I_{R}, I_{S}, I_{T}$ adalah arus masing-masing fase yang di serap oleh beban instalasi (A), dan $i$ merupakan Id_Panel instalasi.

\subsubsection{Ekivalen Analisis Model}

a) Penilaian pembebanan circuit breaker $\left(l_{c b}\right)$

Pada umumnya setiap peralatan listrik ditandai untuk menyatakan daya nilai nominalnya [3]. Masih berdasarkan electrical instalation guide acording to IEC international standar disebutkan bahwa nilai rating $\mathrm{CB}$ In adalah arus nilai arus maksimum $\mathrm{CB}$ yang dapat dialirkan secara terus-menerus pada suhu ambient yang ditetapakan oleh pabrik tanpa mengalami trip [3]. Sedangkan berdasarkan PUIL 2000, arus nominal rating sebuah $\mathrm{CB}$ adalah nilai arus operasi yang mendasari pembuatan perlengkapan listrik dapat bekerja [6]. Oleh karena itu pada dasarnya CB boleh dibebani hingga beban CB $100 \%$. Hal ini karena CB dirancang untuk mampu melayani beban-beban hingga nilai maksimum sesuai dengan kapasitas $\mathrm{CB}$ atau nilai rating yang tertera pada badan $\mathrm{CB}$. Namun demikian sesuai dengan kaidah-kaidah dan aturan kelistrikan untuk menjamin quality dan safety dalam instalasi kelistrikan disebutkan bahwa "setiap perlengkapan listrik tidak boleh dibebani melebihi kemampuannya" [6].

Dengan menggunakan domain penilaian dalam rentang dari 1 s.d 10 dan pendekatan aturan penilaian seperti pada Tabel 1 sebagai representasi dari aturan bahwa "salah satu cara sederhana untuk menentukan reliability suatu utilitas perangkat/peralatan sistem teknik tenaga listrik adalah dengan menentukan reserve margin adalah sekitar 20 - 25\%" [8], maka fungsi penilaian pembebanan $\mathrm{CB}$ utama pada sebuah panel instalasi listrik pada gedung $l_{C B i}{ }^{\prime}$ dapat dimodelkan seperti pada Persamaan 7 dan 8.

Tabel 1. Dimensional score penilaian pembebanan peralatan instalasi

\begin{tabular}{|l|l|}
\hline Dimensional score & Description \\
\hline 10 & very good \\
\hline greater than 7 & Good \\
\hline from 6 to 7 & Fair \\
\hline less than 6 & Poor \\
\hline 1 & very poor \\
\hline
\end{tabular}

$$
\begin{aligned}
& l_{c b_{i}}=f\left(l_{c b_{i}}\right)
\end{aligned}
$$

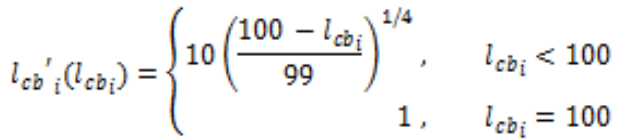


b) Penilaian pembebanan kabel instalasi $\left(l_{b}\right)$

Pada dasarnya kabel didesain adalah memiliki kemampuan sebesar nilai rating atau nilai kapasitasnya (KHA). Meskipun demikian untuk alasan kualitas dan keamanan instalasi, bahwa "peralatan instalasi tidak boleh dibebani melebihi kapasitasnya" [6]. Oleh karena itu sebagaimana dalam menentukan penilaian pembebanan $\mathrm{CB}$, maka pendekatan untuk menentukan penilaian variabel pembebanan kabel pada suatu instalasi listrik dalam panel listrik pada gedung $\left(l_{b i}{ }^{\prime}\right)$ dapat juga dimodelkan sebagai suatu fungsi nilai variabel pembebanan kabel $\left(l_{b i}\right)$ seperti pada Persamaan 9 dan 10.

$$
\begin{aligned}
& l_{b_{i}}{ }^{D}=f\left(l_{b_{i}}\right) \\
& l_{\vec{b}_{\bar{i}}}{ }^{\circ}\left(l_{b_{\bar{i}}}\right)=\left\{\begin{aligned}
10\left(\frac{100-l_{b_{\bar{i}}}}{99}\right)^{1 / 4}, & l_{b_{\bar{i}}}<100 \\
1, & l_{\bar{b}_{\bar{i}}}=100
\end{aligned}\right.
\end{aligned}
$$

\section{c) Penilaian Ketidakimbangan Beban $(\mathcal{E})$}

Dalam persyaratan umum instalasi listrik (PUIL 2000) disebutkan bahwa salah satu faktor yang mungkin berpengaruh menyebabkan efek merusak perlengkapan atau menggangu suplai selama pelayanan normal antara lain adalah beban tak imbang [6]. Meskipun secara ideal kondisi arus seimbang tidak akan pernah tercapai, namun ketidakimbangan yang terjadi harus diminimalkan [9]. Dalam berbagai jurnal ilmiah disebutkan bahwa, akibat pembebanan yang tidak seimbang menyebabkan rugi-rugi daya dalam penyaluran energi listrik semakin besar [7]. Selain itu, meningkatnya arus pada saluran netral pada sistem tiga fase menyebabkan meningkatnya tegangan jatuh (drop voltage) pada saluran netral-ground yang juga menghasilkan efek harmonisa pada saluran netral [10].

Pendekatan penentuan variabel ketidakimbangan beban instalasi $(\mathcal{E})$ dalam penelitian ini adalah berdasarkan definisi ketidakimbangan tegangan oleh NEMA (The National Electrical Manufacturers Association). Dengan mengganti parameter-parameter tegangan menjadi arus, maka untuk menentukan ketidakimbangan beban pada penelitian ini dapat digunakan persamaan sebagaimana dituliskan pada Persamaan 5.

Berdasarkan kurva derating factor NEMA, aturan ketidakimbangan tegangan yang menyebutkan bahwa ketidakimbangan tegangan menyebabkan ketidakimbangan arus fase $6-10$ kali persen ketidakimbangan tegangan [9], serta domain nilai ketidakimbangan beban yang digunakan dalam rentang $[0,200 \%]$ maka dengan menggunakan skala penilaian dari 1 s.d. 10 dan pendekatan aturan penilaian seperti pada Tabel 2, penilaian variabel ketidakimbangan beban instalasi dalam sebuah panel instalasi listrik $\mathcal{E}_{i}^{\prime}$ dapat dimodelkan sebagai suatu fungsi nilai ketidakimbangan beban pada panel instalasi $\mathcal{E}_{i}$ seperti pada Persamaan 11 dan 12.

Tabel 2. Dimensional score penilaian ketidakimbangan

\begin{tabular}{|c|c|}
\hline Dimensional score & Description \\
\hline 10 & very good \\
\hline Greather than 7 & Good \\
\hline From 4 to 7 & Fair \\
\hline Less than 4 & Poor \\
\hline 1 & very poor \\
\hline \multicolumn{2}{|l|}{$\varepsilon_{\mathrm{i}}=f\left(\varepsilon_{\mathrm{i}}\right)$} \\
\hline$\left(\varepsilon_{i}\right)=\left\{10\left(\frac{200-\varepsilon_{i}}{199}\right)^{11 / 1,25)^{2}}\right.$, & $\begin{array}{l}\varepsilon_{i}<=10 \\
10<\varepsilon_{i}<200 \\
\varepsilon_{i}=200\end{array}$ \\
\hline
\end{tabular}
beban instalasi

d) Penilaian usia instalasi $\left(r_{u}\right)$

Berdasarkan UU No.30 Tahun 2009 tentang ketenagalistrikan disebutkan bahwa pada dasarnya setiap instalasi listrik yang telah beroperaasi adalah laik (qualified), telah memenuhi unsur quality dan safety instalasi listrik yang dipersyaratkan. Namun demikian seiring bertambahnya usia instalasi (service live) maka instalasi listrik dan peralatannya akan mengalami degadrasi dan deteriorasi [5]. Tidak adanya standar baku yang mengatur atau membahas mengenai lifespan, service live peralatan instalasi suatu instalasi listrik pada gedung, maka penilaian usia instalasi listrik terkait dengan kondisi/integritas instalasi pada suatu gedung adalah menjadi rumit. Maka dari itu sebagai pendekatan dalam menggunakan variabel usia instalasi (u) sebagai sebuah saverity factor untuk menilai kondisi kesehatan instalasi listrik suatu gedung, pendekatan yang dapat digunakan dalam penelitian ini adalah dengan mengacu pada pedoman indikasi umur ekonomis suatu bangunan.

Indikasi umur ekonomis suatu bangunan adalah periode waktu untuk aset/bangunan yang diharapkan dapat digunakan/dimanfaatkan secara ekonomis sesuai fungsinya dengan asumsi konstruksi/instalasi bangunan adalah sesuai dengan norma-norma (standar) yang berlaku di Indonesia secara terus menerus dimanfaatkan sesuai fungsinya dan dilakukan perawatan secara teratur. Indikasi umur ekonomis gedung/bangunan yang digunakan sebagai pendekatan untuk dalam penelitian ini adalah indikasi umur ekonomis suatu bangunan yang dikeluarkan oleh asosiasi Masyarakat Profesi Penilai Indonesia (MAPPI). Berdasarkan indikasi umur ekonomis bangunan maka usia ekonomis sebuah bangunan gedung pemerintah untuk pendidikan (objek penelitian) adalah selama 50 tahun. Oleh karena itu 
dengan menggunakan domain usia instalasi gedung dalam rentang 1 s.d. 100 tahun dan nilai severity factor kesehatan instalasi listrik $r_{u}$ dari 0 s.d. 1,0 (Tabel 3), maka nilai $r_{u}$ untuk usia instalasi $u$ dapat diperkirakan dengan pendekatan Persamaan 13 dan 14 (meskipun nilainya bisa lebih rendah atau tinggi tergantung dari faktor-faktor lain seperti faktor maintenance, dan prilaku pemanfaatan energi listrik dalam gedung).

$$
\begin{gathered}
r_{u_{i}}=f\left(u_{i}\right) \\
r_{u_{i}}\left(u_{i}\right)=\left\{\begin{aligned}
1, & u_{i} \leq 15 \\
\left(\frac{100-u_{i}}{99}\right)^{1 / 2}, & 15<u_{i} \leq 60 \\
0,6, & 60<u_{i} \leq 100
\end{aligned}\right.
\end{gathered}
$$

Tabel 3. Dimensional score severity factor usia instalasi

\begin{tabular}{|l|l|}
\hline \multicolumn{1}{|c|}{ Dimensional score } & Description \\
\hline Greather than 0,9 & Good \\
\hline From 0,7 to 0,9 & Fair \\
\hline Less than 0,7 & Poor \\
\hline
\end{tabular}

e) Penilaian kesehatan instalasi $(h)$

Variabel kesehatan instalasi (h) adalah output dari sistem komputasi evaluasi tingkat kesehatan instalasi yang merupakan fungsi dari variabel-variabel input sistem yang berupa parameter-parameter instalasi. Sebagaimana pendekatan yang dilakukan bahwa penilaian tingkat kesehatan instalasi pada penelitian ini adalah mengacu pada laporan Final electrical safety audit report [11] yaitu menggunakan penilaian dengan rentang nilai dari 1 s.d. 10 yang nilai 1 berarti buruk dan nilai 10 adalah sangat baik (Tabel 4).

Selain itu juga sebagaimana pendekatan dalam proses komputasi Gambar 2, bahwa untuk menentukan tingkat kesehatan instalasi listrik pada suatu panel instalasi $h_{i}{ }^{\prime}$ dapat diperoleh berdasarkan nilai kualitas pembebanan instalasi $\lambda$ dan saverity factor kondisi instalasi $r_{u}, r_{t p}$ dari masing-masing panel instalasi. Maka dari itu untuk mengevaluasi dan menentukan tingkat kesehatan instalasi di setiap panel instalasi listrik, Persamaan 6 dapat diturunkan ke dalam Persamaan 15, 16 dan 17.

Tabel 4. Dimensional score tingkat kesehatan instalasi

\begin{tabular}{|l|l|}
\hline \multicolumn{1}{|c|}{ Dimensional score } & Description \\
\hline 10 & Very good \\
\hline Greather than 7 & Good \\
\hline From 6 to 7 & Fair \\
\hline
\end{tabular}

$$
\begin{aligned}
& \begin{array}{|l|l|}
\hline \text { Less than } 6 & \text { Poor } \\
\hline 1 & \text { Very poor } \\
\hline
\end{array} \\
& h_{i}=f\left(l_{c b_{i}}, l_{b_{i}}, \varepsilon_{i}, u_{1}, t_{p_{i}}\right) \\
& h_{i}=\lambda_{l_{i}} \cdot r_{u_{i}} \cdot r_{t p_{i}} \\
& \lambda_{i}=\operatorname{avg}\left(l_{c b_{i}}{ }^{\prime}, l_{b_{i}}, \varepsilon_{i}^{\prime}\right) \\
& h_{i}=\operatorname{avg}\left(l_{c b_{i}}, l_{b_{i}}, \varepsilon_{i}^{\prime}\right) \cdot r_{u_{i}}, r_{t p_{i}}
\end{aligned}
$$

Dengan $\lambda$ merupakan kualitas pembebanan instalasi, $r_{u}$ adalah severity factor usia instalasi, $r_{t}$ adalah severity factor temperatur pada panel instalasi, $i$ adalah Id panel instalasi yang dievaluasi, $h$ adalah kesehatan instalasi.

\section{3 Implementasi}

Implementasi dari penelitian ini adalah sebuah aplikasi berupa aplikasi desktop. Implementasi aplikasi desktop pada penelitian ini dibangun dengan menggunakan perangkat lunak Microsoft Visual Studio Community 2015 Version 14.0 dan bahasa pemrograman yang digunakan adalah bahasa pemrograman C\# (Csharp).

\section{Hasil dan Pembahasan}

Pengujian aplikasi komputasi tingkat kesehatan instalasi listrik dilakukan dengan cara mengimplementasikan aplikasi untuk mengevaluasi kesehatan instalasi listrik pada instalasi listrik Gedung S2/S3 FMIPA UGM Yogyakarta. Data instalasi yang digunakan untuk pengujian adalah data riil berupa nilai-nilai maksimum hasil pengamatan dan pengukuran sesaat pada instalasi kelistrikan di Gedung S2/S3 FMIPA UGM yang dilakukan antara bulan Maret-April 2016 pada saat pemakaian energi listrik pada waktu-waktu beban puncak (WBP).

Sebagai ilustrasi dari proses ini sebuah contoh evaluasi pada Panel LP-LT.01 adalah diberikan data sebagai berikut:

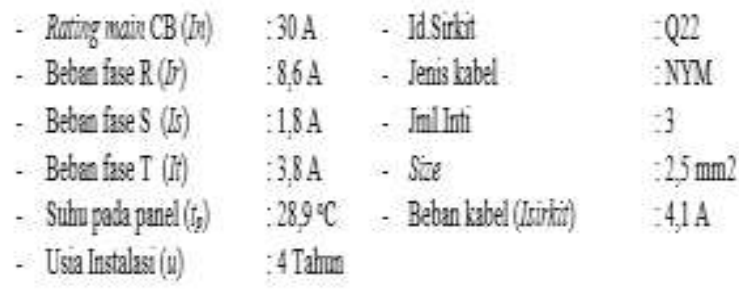

Berdasarkan Persamaan 1, 2 dan 3, maka nilai pembebanan $\mathrm{CB}$ pada Panel $\left(l_{C B i}\right)$ dapat diketahui dengan menentukan nilai kapasitas $\mathrm{CB}\left(C B_{c}\right)$ dan beban $\mathrm{CB}\left(C B_{L}\right)$ terlebih dahulu. Hasil komputasi : 


$$
\begin{aligned}
C B_{c} & =\frac{\sqrt{3} \times V_{2} \times I_{n}}{1000} \\
& =\frac{\sqrt{3} \times 380 \mathrm{~V} \times 30 \mathrm{~A}}{1000} \\
& =19,7 \mathrm{kVA} \\
C B_{c} & =\frac{\sqrt{3} \times V_{2} \times I_{n}}{1000} \\
& =\frac{\sqrt{3} \times 380 \mathrm{~V} \times 30 \mathrm{~A}}{1000} \\
& =19,7 \mathrm{kVA} \\
l_{c b} & =\frac{C B_{2}}{C B_{c}} \times 100 \% \\
& =\frac{3.1 \mathrm{kVA}}{19.7 \mathrm{kVA}} \times 100 \% \\
& =15,7 \%
\end{aligned}
$$

Dengan diketahuinya nilai pembebanan $\mathrm{CB} l_{c b}$ pada Panel LP-LT.01 yaitu sebesar 15,7\%, maka selanjutnya dapat dilakukan penilaian terhadap nilai pembebanan $\mathrm{CB}$ tersebut sebagai salah satu variabel kesehatan instalasi $l_{c b}{ }^{\prime}$ yakni dengan melakukan ekivalen analisis menggunakan Persamaan 7, 8, dan Tabel 1 .

$$
\begin{aligned}
& l_{c b_{i}}{ }^{n}=f\left(l_{c b_{i}}\right) \\
& l_{c b}^{\prime}{ }_{L F-2 T .01}(15,7)=10\left(\frac{100-15,7}{99}\right)^{1 / 4} \\
& l_{c b} \dot{L}_{L-t 7.04}(15,7)=9,61 \\
& l_{c b}^{\prime} \text { Lp-LT.01 }(15,7)=\text { Greather than } 7 \\
& l_{c b}{ }_{L 2-27.04}(15,7)={ }^{\prime} G_{0 o d}
\end{aligned}
$$

Untuk pengamatan pembebanan kabel instalasi listrik pada Panel LP-LT.01, sirkit instalasi yang diamati adalah sirkit Q22. Jenis dan ukuran kabel sirkit Q22 adalah NYM $3 \times 2,5 \mathrm{~mm}^{2}$. Nilai KHA kabel instalasi Q22 berdasarkan data sheet adalah 25 A. Dengan nilai arus beban (Isirkit) adalah 4,1A, maka berdasarkan Persamaan 4 nilai pembebanan kabel instalasi pada Panel LP-LT.01 $\left(l_{b}\right)$ dapat ditentukan yaitu:

$$
\begin{gathered}
l_{b}=\frac{I_{\text {Sirkit }_{i}}}{\text { KHA }_{\text {Sirkit }_{i}}} \times 100 \% \\
l_{b}=\frac{4,1 \mathrm{~A}}{25 \mathrm{~A}} \times 100 \% \\
l_{b}=16,4 \%
\end{gathered}
$$

Dengan telah diketahuinya nilai beberapa parameter instalasi listrik pada Panel LP-LT.01, yaitu: Pembebanan circuit breaker $l_{c b}{ }^{\prime}{ }_{L P-L T: 01}(15,7 \%)=9,61$ (good). Pembebanan kabel $\quad l_{b}{ }^{\prime}{ }_{L P-L T .01}(16,4 \%)=9,59 \quad$ (good) . Ketidakimbangan beban instalasi $\varepsilon_{L P-L T: 01}^{\prime}(84,3 \%)=7,07($ good $)$. Severity factor usia instalasi $r_{u_{L P-L T: 01}}(4$ Tahun $)=1 \quad, 0 \quad($ good $)$. Severity factor temperatur pada panel $r_{t p_{L T-L P .01}}\left(28,9^{\circ} \mathrm{C}\right)=1,0$ (normal). Maka tingkat kesehatan instalasi listrik pada panel LP-LT.01 dapat diketahui. Dengan menentukan kondisi pembebanan instalasi $\lambda_{l}$ terlebih dahulu menggunakan Persamaan 16, kemudian menerapkan Persamaan 15 dan Tabel 4, tingkat kesehatan instalasi listrik $h$ pada panel LP-LT.01 dapat ditentukan.

$$
\begin{aligned}
& \lambda_{l_{i}}=\operatorname{avg}\left(l_{\mathrm{cb}_{j}}^{\prime}, t_{b_{j}}^{\prime}, \varepsilon_{\mathrm{i}}^{\prime}\right) \\
& \lambda_{l_{L P}-L T .01}=\operatorname{avg}(9.61,9.59,7.07) \\
& \lambda_{L P P-L T .01}=8,75 \\
& h_{\mathrm{i}}=\lambda_{i_{\mathrm{i}}} \cdot r_{\mathrm{u}_{\mathrm{i}}} \cdot r_{\mathrm{tp}} \\
& h_{\text {LP-LT.01 }}=8,75 \cdot 1,0 \cdot 1,0 \\
& h_{\text {LP-LT.01 }}=8,75 \\
& h_{\text {LP-LT.01 }}=\text { Greather } \text { than } 7 \\
& h_{\text {LP-LT.01 }}=\text { 'GoOd' }
\end{aligned}
$$

Jadi dari proses komputasi yang telah dilakukan, maka tingkat kesehatan instalasi listrik pada instalasi listrik Panel LP.LT.01 dapat diketahui yaitu termasuk dalam kategori 'baik' atau 'good' dengan nilai 8,75.

Hasil implementasi komputasi tingkat kesehatan instalasi listrik pada instalasi listrik Gedung S2/S3 FMIPA UGM di bulan Maret - April 2016 secara secara keseluruhan memperlihatkan bahwa kondisi instalasi listrik di Gedung S2/S3 adalah 'Baik' atau 'Good' sebagaimana diperlihatkan pada Gambar 4 dan 5.

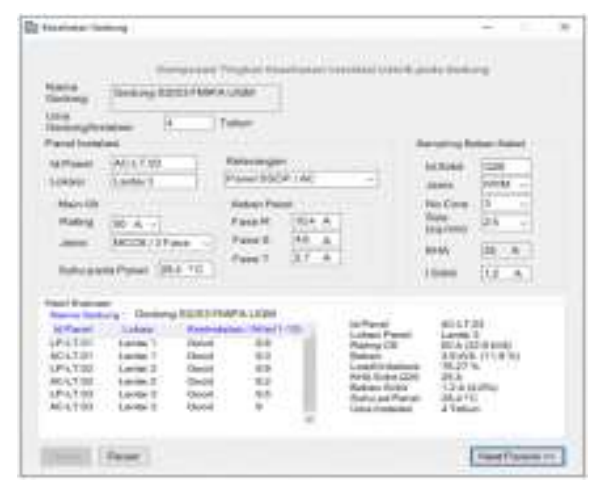

Gambar 4. Contoh implementasi komputasi tingkat kesehatan instalasi listrik Gedung S2/S3 FMIPA UGM bulan Maret-April 2016. 


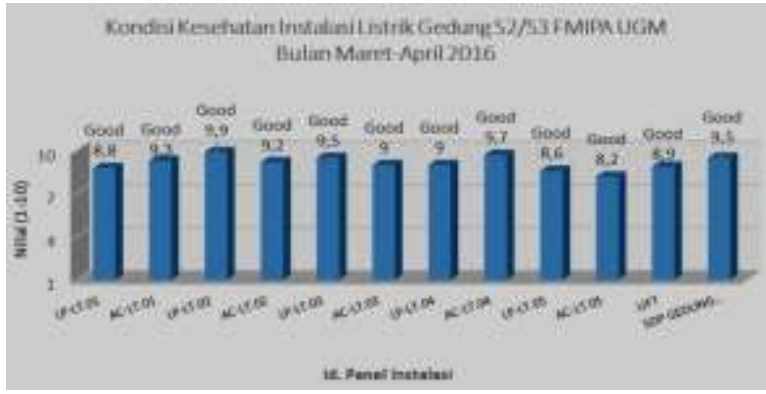

Gambar 5 Hasil implementasi aplikasi mengevaluasi tingkat kesehatan instalasi listrik Gedung S2/S3

FMIPA UGM bulan Maret-April 2016.

\section{Kesimpulan}

Kesehatan instalasi listrik sebuah gedung/bangunan dapat ditentukan dengan melakukan komputasi melalui ekivalen analisis terhadap beberapa parameter instalasi listrik pada gedung seperti; usia instalasi, pembebanan pada $\mathrm{CB}$, pembebanan pada kabel, ketidakimbangan beban instalasi, dan temperatur ambient di setiap panel instalasi.

Hasil penelitian menunjukkan, komputasi kesehatan instalasi listrik yang dilakukan pada instalasi listrik Gedung S2/S3 FMIPA UGM bulan Maret-April 2016 memperlihatkan bahwa; secara garis besar kondisi kesehatan instalasi listrik di gedung S2/S3 UGM pada bulan Maret - April 2016 adalah baik yaitu dalam skala 1 s.d. 10 tingkat kesehatan instalasi listrik secara keseluruan di atas nilai 7,0.

Analisis ekivalen model komputasi parameter-parameter instalasi untuk menentukan tingkat kesehatan instalasi listrik pada gedung adalah didasarkan pada aturan-aturan instalasi. Mengingat banyaknya aturan instalasi di dalam teknik ketenagalistrikan (multi variabel) dan pada umumnya adalah tidak detail (imprecise) maka perlu dilakukan penelitian dengan metode lain seperti pendekatan dengan fuzzy logic, sistem pakar, dll.

Pengamatan dan pengambilan data untuk dievaluasi masih dilakukan secara manual melalui pengukuran menggunakan alat-alat ukur listrik, dapat digantikan dengan memasang sensor-sensor elektronik sehingga bisa kembangkan ke dalam bentuk model smart sistem evaluation.

\section{Daftar Pustaka}

[1] Babrauskas, V., Mechanisms and Modes for Ignition of Low-Voltage PVC Wires, Cables, and Cords, Proceeding of Fire and Materials, London, 2005.
[2] Billinton, R, and Allan, R, N., Reliability Evaluation of Power Systems Second Edition, Plenumm Press, New York, 1996.

[3] Schneider Electric, Electrical Installation Guide 2009 According to IEC International Standar, 2008.

[4] Gautam, K, K., and Buria, V., Fuzzy Logic Application in Power System Fault Diagnosis, Indian Journal of Computer Science and Engineering (IJCSE), Vol. 2, No.4, 554-558, 2011.

[5] Hyvonen, P., Prediction of Insulation Degradation of Distribution Power Cables Based on Chemical Analysis and Electrical Measurements, Doctoral Dissertation, Department of Electrical Engineering, Helsinki University of Technology, 2008.

[6] SNI 04-0225-2000, Persyaratan Umum Instalasi Listrik 2000 (PUIL 2000), BSN, Jakarta, 2000.

[7] Reese, C, and Hofmann, L., Analysis and Reduction of Effects of Single-Phase Loads and Generators on Low Voltage Distribution Grids, in 21 st International Conference on Electricity Distribution, Frankfurt, 2011.

[8] Meier, A. V., Electric Power System: A Conceptual Introduction, John Wiley \& Sons, Inc., Canada, 2006.

[9] Soemarno, Voltage Unbalance Penyebab over Heating,

http://soemarno.org/2008/06/24/voltage-unbalanc e-penyebab-over-heating/, 2008, diakses tgl 28 Januari 2016.

[10]Dey, N, and Chakraborty, A., Neutral Current and Neutral Voltage in a Three Phase Four Wire Distribution System of a Technical Institution, International Journal of Computer Applications, Vols. 72, No.3, , 2013.

[11]URS Martin Technical Zoubek Consulting, Final Electrical Safety Audit Report for Port of Los Angeles, URS Martin Technical Zoubek Consulting, LCC Safety Solutions, San Pedro, 2013. 